\title{
Students' Perception of the Availability and Utilization of Information and Communication Technology (ICT) in the Teaching and Learning of Science Subjects in Secondary Schools in Ekiti State, Nigeria
}

\author{
Jegede, Samuel Akingbade \\ Department of Curriculum Studies, Faculty of Education, \\ Ekiti State University, Ado-Ekiti, Nigeria \\ E-mail: canonsamakjeg@yahoo.com
}

Received: 17-05- 2013

Accepted: 27-06- 2013

Published: 01-07- 2013

doi:10.7575/aiac.ijels.v.1n.1p.94

URL: http://dx.doi.org/10.7575/aiac.ijels.v.1n.1p.94

\begin{abstract}
The study investigated students' perception of the availability and utilization of Information and Communication Technology (ICT) in the teaching and learning of science subjects in secondary schools in Ekiti State, Nigeria. The population of the study was made up of all secondary school students in public and private secondary schools in Ekiti State, Nigeria. The sample was 400 students selected from both public and private secondary schools in the state using the multi-stage sampling. The only instrument used in collecting relevant data for the study was a questionnaire consisting of two sections A and B. Section A consisted of personal biodata of the respondents, while section B consisted of 22 items which elicited information on the application of ICT in schools for learning science. Four research questions were raised and two hypotheses tested. Data collected were analysed using frequency counts and percentages as well as inferential statistics of t-test. The results showed that apart from the computer, which is available in most schools, the other identified ICT equipment were not available. The findings also showed that there is no significant difference in the availability of ICT facilities in public and private secondary schools, and that students in private schools are more exposed to ICT than their counterparts in public schools.
\end{abstract}

Keywords: Perception, Availability, Utilization, Teaching, Learning

\section{Introduction}

Education is the pivot on which the growth and development of any nation depends and this is why every nation is striving to educate her citizens irrespective of age. In the time past and now, nearly everybody in the industrialized countries of the world has gained access to the use of ICT. The provision of computers, radio, ancillary equipment, audio tapes and audio-visual tapes, microfilms for on-line learning in schools are not new to citizens of such countries. Besides, a lot of researches have been carried out in these advanced and industrialized countries for the purpose of advancing knowledge on ICT to be used in education. This on the other hand has increased the use of ICT for teaching and learning and consequently has improved access to education in a way that nearly every student has his/her own gadget for use. This is made possible because the governments of these countries do vote a lot of money for the purchase of these gadgets.

Population explosion in secondary schools in Ekiti State in recent years suggests the use of Information and Communication technology (ICT) in the teaching-learning process as its adoption will promote educational interaction between students and teachers and will also enhance effective teaching and learning. This is in consonance with the opinion of Look (2005) that issues like good course organisation, effective classroom management, content creation, self assessment, self study and collaborative learning, task oriented activities and effective communication between the actors of the teaching-learning process and research activities will be enhanced by the use of ICT-based technology. Unfortunately, it is very difficult to have first-hand information on how many of these gadgets are available for use in schools. (Jegede, 2003).

In Africa, many governments have been making plans and looking for a determined way to initiate internet connection and technology training programmes. These programmes link schools around the world in such a way to improve education, enhance cultural understanding and develop skills that are needed by youths to secure jobs in the $21^{\text {st }}$ Century. Examples of such programmes include an interconnectivity programme, known as Uganda School Net developed in extending educational technology throughout Uganda (Okwo, 2000). These programmes in the African countries are sponsored by their governments through the ministry of education. Unlike these countries, Nigeria has not made any significant effort to integrate ICT into her secondary school curriculum.

It is quite unfortunate that, even today, many instructional and administrative works in the Nigerian secondary schools are still carried out manually, many of the files and documents are still kept inside file cabinets where they are 
accumulated with dusts and are often eaten up by termites and rodents, a sympathetic case that has made such files irretrievable!

The state of teaching-learning activities in Nigerian secondary schools calls for review as most of the teachers in the public secondary schools still practice the traditional method of "chalk and talk" in the classroom. The traditional method of teaching appears to limit the extent to which students and teachers alike can move with the trend of changes across the globe. Although, the chalkboard and textbooks have been used for educational purposes over the years, it appears the system is fast becoming obsolete as it makes the teacher the only repository of knowledge with little or nothing from the students. This appears to make the students lag behind in the scheme of things in the world.

As opined by Ajayi (2008), teaching and learning has advanced beyond the teacher standing in front of a group of pupils and disseminating information to them without the students' active participation. He posited that with the aid of ICT, teachers can take students beyond traditional limits, ensure their active participation in teaching and learning process and create conducive environments within which they can experiment and explore.

In spite of the availability of cyber-cafe here and there; it appears as if secondary school students still find it difficult to make good use of ICT for educational purposes. To this end, the following research questions were raised to guide the study:

\section{Research Questions}

i. How available are ICT facilities in the secondary schools and to what extent are they used in the teaching and learning of science?

ii. What is the level of exposure of science students to the utilisation of ICT?

iii. What are the problems faced by the science students in the application of ICT?

iv. What are the benefits of using ICT in the teaching and learning of science as perceived by the students?

\section{Research Hypotheses}

The following hypotheses were tested at 0.05 level of significance:

1. There is no significant difference in the availability of ICT facilities in public and private secondary schools in Ekiti State.

2. There is no significant difference in the level of exposure of science students to ICT in public and private schools.

\section{Research Design}

The study is a survey type of the descriptive research because it studied a large area from which some schools considered to be representative of the entire group was used.

\subsection{Population}

The population of this study was made up of all the secondary school students in public and private secondary schools in Ekiti State, Nigeria.

\subsection{Sampling and Sampling Techniques}

The sample for the study consisted of 400 students selected from both public and private secondary schools in the State using the multistage sampling technique. The first stage involved the random selection of eight Local Government Areas (LGAs) from the 16 LGAs in the state. The next stage involved random selection of three public and two private schools from each of the selected LGAs. The last stage is the random selection of ten students from each of the selected schools. In all, four hundred students were used for the study.

\subsection{Research Instrument}

The only instrument used to collect relevant data for this study was a questionnaire entitled 'Availability and Utilisation of Information and Communication Technology (ICT) in the Teaching and Learning of Science Subjects (AUICTTLLS)'. The instrument had two sections: A and B. Section A sought information on the bio-data of the respondents (such as name of school, sex, age and class), while Section B contained 22 items designed to elicit information on the application of ICT in schools for learning science. This was structured in a 4-point Likert scale type of Strongly Agree (4), Agree (3), Disagree (2) and Strongly Disagree (1). Each respondent was made to tick the appropriate option.

\subsection{Validity of the Instrument}

The instrument used for the study was subjected to scrutiny by two experts from each of Tests and Measurement, ICT and Curriculum and Instruction for face and content validity. Their corrections were used to modify and restructure the instrument. The modified version was then used for data collection.

\subsection{Reliability of the Instrument}

In order to establish the reliability of the instrument used for this study, the test-retest method of reliability was adopted. The instrument was administered to 25 students from two schools in a Local Government outside the sample used for the study. The instrument was administered on them within an interval of two weeks. The scores from the responses 
were correlated using Pearson Product Moment Correlation analysis. The instrument yielded a reliability co-efficient of 0.76 and was therefore adjudged to be reliable for the study.

\subsection{Administration of the Instrument}

The data for this study were collected by the researcher with the help of research assistants. The researcher trained the research assistants for the administration of the instruments. The researcher visited schools to monitor the research assistants for the proper administration of the questionnaire to the students. Copies of the returned questionnaires were then collated for data analysis.

\section{Data Analysis}

The data collected for the study were analysed using descriptive statistics such as frequency counts, percentages, mean and standard deviation, while the inferential statistics used was the t-test statistics. All hypotheses formulated were tested at 0.05 level of significance.

\section{Results}

This section presents the analysis of the data collected.

Research Question 1: How available are ICT facilities in the secondary schools and to what extent are they used in the teaching and learning of science?

Table 1. Frequency and percentage distribution showing the availability of ICT facilities in public and private schools

\begin{tabular}{|c|c|c|c|c|c|c|c|c|}
\hline \multirow[b]{3}{*}{ ICT Facilities } & \multicolumn{4}{|c|}{ Public Schools } & \multicolumn{4}{|c|}{ Private Schools } \\
\hline & \multicolumn{2}{|c|}{ Available } & \multicolumn{2}{|c|}{ Not Available } & \multicolumn{2}{|c|}{ Available } & \multicolumn{2}{|c|}{ Not Available } \\
\hline & $f$ & $\%$ & $f$ & $\%$ & $f$ & $\%$ & $f$ & $\%$ \\
\hline Computer & 123 & 82.0 & 27 & 18.0 & 58 & 96.7 & 2 & 3.3 \\
\hline Internet Facilities & 12 & 8.0 & 138 & 92.0 & 5 & 8.3 & 55 & 91.7 \\
\hline Satellite dish & 19 & 12.7 & 131 & 87.3 & 11 & 18.3 & 49 & 81.7 \\
\hline e-mail account & 22 & 14.7 & 128 & 85.3 & 12 & 20.0 & 48 & 80.0 \\
\hline Scanner & 29 & 19.3 & 121 & 80.7 & 15 & 25.0 & 45 & 75.0 \\
\hline Electronic notice boards & 11 & 7.3 & 139 & 92.7 & 6 & 10.0 & 54 & 90.0 \\
\hline Digital camera & 20 & 13.3 & 130 & 86.7 & 10 & 16.7 & 50 & 83.3 \\
\hline Camcorders & 18 & 12.0 & 132 & 88.0 & 3 & 5.0 & 57 & 95.0 \\
\hline Projectors & 45 & 10.0 & 135 & 90.0 & 6 & 10.0 & 54 & 90.0 \\
\hline Television sets & 23 & 22.0 & 117 & 78.0 & 22 & 36.7 & 38 & 63.3 \\
\hline Video & 20 & 13.3 & 130 & 86.7 & 13 & 21.7 & 47 & 78.0 \\
\hline Slides & 20 & 13.3 & 130 & 86.7 & 9 & 15.0 & 51 & 85.0 \\
\hline Film strips & 3 & 2.0 & 147 & 98.0 & 2 & 3.3 & 58 & 96.7 \\
\hline Radio/Tape Recorder & 46 & 30.7 & 194 & 69.3 & 24 & 40.0 & 36 & 60.0 \\
\hline Disc player & 21 & 14.0 & 129 & 86.0 & 12 & 20.0 & 148 & 80.0 \\
\hline
\end{tabular}

From the above table which shows the percentage availability of the listed ICT facilities, computer set is the only available ICT facility in both public and private secondary schools in the State. Hence, it can be concluded that ICT facilities are grossly inadequate in secondary schools in Ekiti State.

Research Question 2: What is the level of exposure of science students to the use of ICT?

Table 2. Frequency and percentage distribution table showing the level of exposure of science students to ICT

\begin{tabular}{|c|l|l|l|l|l|}
\hline \multirow{2}{*}{$\boldsymbol{S} / \boldsymbol{N}$} & \multicolumn{1}{|c|}{ Items } & \multicolumn{2}{c|}{ Exposed } & \multicolumn{1}{c|}{ Not Exposed } \\
\cline { 3 - 5 } & \multicolumn{1}{|c|}{$\mathbf{f}$} & $\mathbf{\%}$ & \multicolumn{1}{|c|}{$\mathbf{f}$} & \multicolumn{1}{c|}{$\%$} \\
\hline 1. & There are ICT facilities in my school. & 246 & 61.5 & 154 & 38.6 \\
\hline 2. & ICT facilities in my school are adequate. & 182 & 45.5 & 218 & 54.5 \\
\hline 3. & ICT facilities in my school are efficient. & 197 & 49.2 & 203 & 50.8 \\
\hline 4. & Students have access to ICT in my school & 199 & 49.7 & 201 & 50.3 \\
\hline 5. & Students are competent to make use of computers in my school. & 217 & 54.2 & 183 & 45.8 \\
\hline 6. & $\begin{array}{l}\text { The various forms of ICT facilities in my school are being used } \\
\text { regularly. }\end{array}$ & 170 & 42.6 & 230 & 57.5 \\
\hline 7. & $\begin{array}{l}\text { Students have opportunity of attending computer training } \\
\text { programme. }\end{array}$ & 250 & 62.5 & 150 & 37.5 \\
\hline 8. & Periodic training is organized for students on the use of ICT. & 209 & 52.2 & 191 & 47.8 \\
\hline 9. & Students have e-mail addresses and can check their e-mail. & 194 & 48.4 & 206 & 51.6 \\
\hline 10. & Students are knowledgeable in the use of ICT. & 279 & 69.8 & 121 & 30.2 \\
\hline
\end{tabular}


The result in Table 2 shows that $246(61.5 \%)$ of the students reported the there are ICT facilities in their school while $154(38.6 \%)$ reported that they do not have. $218(54.5 \%)$ of the students also indicated that the available ICT facilities available in their schools are not adequate while $182(45.5 \%)$ indicated that the available ICT facilities in their schools are adequate. 197 (49.2\%) students declared that the available ICT facilities in their schools are effective while 203 $(50.8 \%)$ declared that they are not effective. 199 (49.7\%) reported that they have access to ICT facilities in their schools while $201(50.3 \%)$ of the students reported that they do not have access to ICT. $217(54.2 \%)$ claimed to be competent in making use of computers while $183(45.8 \%)$ claimed not to be competent.

The result further shows that $230(57.5 \%)$ of the students indicated that the various forms of ICT available in their schools are not used regularly while $170(42.6 \%)$ indicated that they are used regularly. $250(62.5 \%)$ students reported that they had opportunity to attend computer training while $150(37.5 \%)$ did not have opportunity to attend computer training. $209(52.2 \%)$ claimed that periodic training are organised for students on the use of ICT while 191 (47.8\%) claimed that periodic training were not organised for students on the use of ICT. 208 (51.6\%) students indicated that they do not have e-mail while $194(48.4 \%)$ indicated that they have e-mail and $279(69.8 \%)$ students reported that they are knowledgeable in the use of ICT while 121 (30.2\%) reported that they are not knowledgeable in the use of ICT.

Research Question 3: What are the problems faced by science students in the application of ICT?

Table 3. Frequency and percentage distribution showing the problems faced by science students

\begin{tabular}{|c|c|c|c|c|c|}
\hline \multirow{2}{*}{$S / N$} & \multirow{2}{*}{ Items } & \multicolumn{2}{|c|}{ Agreed } & \multicolumn{2}{|c|}{ Disagreed } \\
\hline & & $f$ & $\%$ & $f$ & $\%$ \\
\hline 1. & $\begin{array}{l}\text { Irregular power supply is a major hindrance to the use of } \\
\text { ICT facilities in the teaching and learning of science } \\
\text { subjects. }\end{array}$ & 281 & 70.2 & 119 & 29.8 \\
\hline 2. & $\begin{array}{l}\text { There are not enough competent teachers to handle ICT } \\
\text { facilities in my school. }\end{array}$ & 272 & 68.0 & 128 & 32.0 \\
\hline 3. & Lack of funds hinders school from embracing ICT. & 242 & 60.5 & 158 & 39.5 \\
\hline 4. & ICT makes science lessons more difficult. & 110 & 27.5 & 290 & 72.5 \\
\hline
\end{tabular}

Table 5 shows that $281(70.2 \%)$ of the science students believed that instability of power supply constitutes a problem to the application of ICT in science subjects. $272(68 \%)$ of the respondents agreed that schools did not have enough computer teachers. $242(60.5 \%)$ of the students indicated that lack of fund hinders schools from embracing ICT. 110 $(27.5 \%)$ of the respondents reported that ICT makes lesson more simplified.

Research Question 4: What are the benefits of using ICT in the teaching and learning of chemistry as perceived by the students?

Table 4. Frequency and percentage distribution of the benefits of ICT to the teaching and learning of chemistry as perceived by the students

\begin{tabular}{|c|l|c|c|c|c|}
\hline \multirow{2}{*}{$S / N$} & \multicolumn{1}{|c|}{ Items } & \multicolumn{1}{c|}{ Agreed } & \multicolumn{2}{c|}{ Disagreed } \\
\cline { 3 - 5 } & \multicolumn{1}{|c|}{$\boldsymbol{f}$} & $\%$ & $\boldsymbol{f}$ & \% \\
\hline 1. & $\begin{array}{l}\text { ICT enables students to have the ability to access and apply } \\
\text { information in the science class. }\end{array}$ & 355 & 88.7 & 45 & 11.3 \\
\hline 2. & ICT makes it easy to think of new ideas. & 317 & 79.2 & 83 & 20.8 \\
\hline 3. & ICT enhances quality of work of students. & 288 & 78 & 112 & 28.0 \\
\hline 4. & $\begin{array}{l}\text { The use of computer brings reality to practical lessons in } \\
\text { chemistry. }\end{array}$ & 311 & 77.7 & 89 & 22.3 \\
\hline 5. & $\begin{array}{l}\text { The use of ICT in chemistry lessons enables students to take } \\
\text { active parts in the teaching-learning process. }\end{array}$ & 329 & 82.2 & 71 & 17.8 \\
\hline 6. & ICT enables students to acquire knowledge faster and easier. & 366 & 91.5 & 34 & 8.5 \\
\hline 7. & ICT makes learning more interesting. & 359 & 89.7 & 41 & 10.3 \\
\hline
\end{tabular}

Table 4 shows that $359(89.7 \%)$ of the science students believed that ICY makes learning more interesting while 41 $(10.3 \%)$ of them believed that ICT does not make learning more interesting. $45(11.3 \%)$ of the students claimed that ICT does not help the students have the ability to access and apply information in the science class, while 355 (88.7\%) claimed that ICT help the students to have the ability to access and apply information in the science class. 317 (79.2\%) of the respondents also reported that ICT makes it easy to think of new lesson ideas, while $83(20.8 \%)$ of them reported otherwise. $112(28 \%)$ of the students negated the opinion that ICT enhances the quality of work of students and 288 (78\%) were of the opinion that ICT enhances the quality of work of students. $311(77.7 \%)$ declared that the use of computer helps to enhance the practical lessons in science subjects while 89 (22.3\%) also reported otherwise.

Of the respondents, $195(48.8 \%)$ indicated that the use of computer is not limited to computer lessons. $329(82.2 \%)$ of the students claimed that ICT enhances the possibility of students taking important parts in learning, while 71 (17.8\%) 
of them claimed that this is not so and $34(8.5 \%)$ of them also believed that ICT does not enable students to acquire knowledge faster and easier, while $366(91.5 \%)$ believed that it enables students to acquire knowledge faster and easier.

\section{Testing of Hypothesis}

$\boldsymbol{H O}_{1}$ : There is no significant difference in the availability of ICT facilities in public and private secondary schools in Ekiti State.

Table 5: t-test showing availability of ICT facilities in public and private schools

\begin{tabular}{|l|c|c|c|c|c|c|}
\hline \multicolumn{1}{|c|}{ Group } & $\boldsymbol{N}$ & Mean & SD & df & t-cal & t-table \\
\hline Public & 150 & 18.98 & 5.61 & \multirow{2}{*}{208} & 1.755 & 1.960 \\
\cline { 1 - 5 } Private & 60 & 20.35 & 3.54 & & & \\
\hline
\end{tabular}

Table 5 shows the t-cal (1.755) is less than t-table (1.960) at 0.05 level of significance. The null hypothesis was not rejected. Therefore, there is no significant difference in the availability of ICT facilities in public and private secondary schools in Ekiti State.

$\mathrm{HO}_{2}$ : There is no significant difference in the level of exposure of science students to ICT in public and private schools.

Table 6. t-test analysis of the level of exposure of science students in public and private schools to ICT

\begin{tabular}{|l|c|c|c|c|c|c|}
\hline \multicolumn{1}{|c|}{ Group } & $\boldsymbol{N}$ & Mean & SD & Df & t-cal & t-table \\
\cline { 1 - 5 } Public & 300 & 24.50 & 5.818 & \multirow{2}{*}{398} & 3.856 & 1.960 \\
\cline { 1 - 5 } Private & 100 & 27.18 & 6.617 & & & \multirow{2}{*}{$\mathrm{P}<0.05$}
\end{tabular}

Table 6 shows that t-calculated (3.856) is greater than t-table (1.960). The null hypothesis was rejected. Therefore, there is a significant difference in the level of exposure of science students in public and private schools to ICT. Students from private schools had a higher mean score (27.18) than their counterparts in public schools. This implies that students of private schools are more exposed to ICT than the students of public schools.

\section{Discussion}

The results of the study were discussed based on the general questions, research questions and the hypothesis as follows: On the issue of availability of ICT facilities in public and private secondary schools, the findings revealed that apart from the computer which is available in most of the schools, all other ICT identified equipment are not available. This does not agree with Mohammed (2006) who observed that ICT equipment like camcorders, data projectors, internet, and video players are adequate and available in the various schools where they carried out their research.

On the issue of exposure of science students to the use of ICT in schools, the findings show that majority of the students have a low level of exposure to the use of ICT facilities. The low level of exposure of the students might not be connected with the non-availability of the ICT facilities in the schools. This agrees with the findings of Jimoh (2007) that the capacity to use ICT by the students in the teaching-learning activities was very low. It is also in line with the findings of Yusuf (2005) which reveals that most of the science students are not knowledgeable enough to use ICT or access the internet.

Moreover, the study showed that irregular power supply in schools, lack of computer literate teachers, high cost of purchasing computer, inadequate facilities to support the utilisation of ICT and the non-inclusion of ICT programme in the teacher training programmes constitute the major problems facing the application of ICT in secondary schools. The findings also shows that there is low level of funding and some governments consider providing ICT equipment in schools as being too costly and difficult to maintain. This is in agreement with the findings of Akubuilo (2007) who asserted that funding is a major constraint to making Nigerians school ICT compliant and that low level of budgetary allocation and poverty among Nigerians have made it difficult to procure ICT equipment for their private use.

Some of the perceived benefits as revealed in the study include making learning more interesting, enhancing the quality of work of students, enhancing active participation of students in the teaching-learning process and making teachers to be up-to-date in their various disciplines among others. This is in concord with the findings of Mohammed (2006) and Nwite (2007).

The finding that there is no significant difference in the availability of ICT facilities in public and private secondary schools is somehow disturbing and contrary to expectation because under normal circumstances, one expects the public schools to be better equipped than the private schools. But the result of the study has shown otherwise. Ironically, it seems proprietors of private schools are more committed to supplying the necessary equipment needed in their schools than does the government. This submission is in line with the findings of Jimoh (2007) who decried low level of facilities in schools. 
The findings also showed that students in private schools are more exposed to ICT than their counterparts in the public schools. This may be connected to the fact that parents of many of the students in private schools have ICT facilities in their home and this will enhance the level of their children's exposure to ICT.

\section{Conclusion}

Based on the findings of this study, it could be concluded that ICT equipment/facilities are not available for the teaching of science subjects in secondary schools. Factors such as low funding, cost, low level of internet connectivity, weak infrastructure, low teledensity, lack of skills, lack of basic infrastructure, dearth of technical support staff and teacherfactor, are factors affecting the application of ICT in the teaching and learning of science. Application of ICT in classroom makes the science lesson more interesting and easy to teach and learn. Effective application of ICT in the teaching and learning of science leads to the effective teaching and learning thereby, improving the performance of science students.

\section{Recommendations}

Based on the findings of this study, it was recommended that:

1. The current level of students' exposure to ICT should be sustained while efforts should be made to improve upon the level of teachers' exposure.

2. It was also recommended that government should provide ICT facilities to the public secondary schools and proprietors/proprietresses of private schools should also be made to provide for their schools.

3. Besides, in order to enjoy the full services of ICT in the teaching-learning process, teachers should be made to utilize ICT in their teaching. Science students and teachers should be given access to ICT resources.

4. Government should increase financial allocation to schools to enable them provide the necessary ICT facilities for usage in their schools.

\section{References}

Ajayi, I. A. (2008). Towards effective use of ICT for teaching in Nigerian colleges of education. Asian Journal of Information Technology. 7(5): 210-214.

Akubuilo, D.U. (2007). Effective utilisation of Information and Communication Technology (ICT) in Science Instruction at the Tertiary Level: Some Inhibiting Factors. In J. B. Babalola, G. O. Akpa, A. O. Ayeni, S. O. Adedeji (eds) Access Equity and Quality in Higher Education. National Association for Educational Administration and Planning (NAEAP) Publications, Ibadan; Awemark Printer. 513-521.

Jimoh, A.T. (2007). Students' attitude towards ICT in Nigerian tertiary institutions. Educational Focus (EDFOC). 1(1): 73-79.

Look, D. (2005). Discussion paper: Impact of technology on education, PUSD Excellence Committee. December. Mohammed, Y. (2006). Factors influencing the implementation of ICT in Jigawa State Schools, Nigeria. An unpublished M.Ed. thesis, University of Ilorin.

Nwite, O. (2007). Utilisation of Information and Communication Technology in schools: problems and suggestions. In J. B. Babalola, G. O. Akpa, A. O. Ayeni, S. O. Adedeji (eds) Access Equity and Quality in Higher Education. National Association for Educational Administration and Planning (NAEAP) Publications, Ibadan; Awemark Printer. $487-497$ Nwosu, A.A. (2003). Integrating ICT into SMT classroom: Status and implications. Proceedings of the $44^{\text {th }}$ STAN Conference: $58-60$

Yusuf, M.O. (2005). Information and Communication Technology: Analysing the Nigerian National Policy for Information Technology. Inter-Educational Journal. 6(3): 316-332. 